\title{
HYDRO-PHYSICAL PROPERTIES OF THREE SOILS CONDUCTED UNDER NO-TILLAGE, MINIMUM CULTIVATION AND PERENNIAL PASTURE
}

\author{
Atributos físico-bidricos de três solos conduzidos sob semeadura direta, cultivo mínimo e pastagem perene
}

Clístenes Antônio Guadagnin; Edgar Ricardo Schöffel2 Helvio Debli Casalinho3 ${ }^{3}$; Ivan Luiz Zilli Bacic ${ }^{4}$; Milton da Veiga ${ }^{5}$

\begin{abstract}
${ }^{1}$ Doutor em Agronomia; Epagri - Empresa de Pesquisa Agropecuária e Extensão Rural de Santa Catarina; Gerência Regional da Epagri de São Miguel do Oeste; guada@epagri.sc.gov.br *Autor para correspondência

2Professor do Programa de Pós-Graduação em Sistemas de Produção Agrícola Familiar; Departamento de Fitotecnia; Faculdade de Agronomia Eliseu Maciel; Universidade Federal de Pelotas; ricardo.schoffel@gmail.com

3 Professor do Programa de Pós-Graduação em Sistemas de Produção Agrícola Familiar; Departamento de Solos; Faculdade de Agronomia Eliseu Maciel; Universidade Federal de Pelotas; helviodc@ufpel.edu.br

4Ph.D in Soil Science; Epagri - Empresa de Pesquisa Agropecuária e Extensão Rural de Santa Catarina; Ciram - Centro de Informações de Recursos Ambientais e de Hidrometeorologia de Santa Catarina; bacic@epagri.sc.gov.br

5Doutor em Ciência do Solo; Curso de Agronomia - Campos Novos; Universidade do Oeste de Santa Catarina; milton.veiga@unoesc.edu.br
\end{abstract}

Artigo enviado em 25/08/2017, aceito em 25/09/2017 e publicado em 10/04/2018.

\begin{abstract}
The use and management of different soil classes can change their physical quality and exert influence in the storage of water available to plants. The objectives of this study were to determine the effects of the use and management systems on the hydro-physical properties of Inceptisols, Oxisols and Alfisols, and analyze the effect of such systems and soil classes in the fraction of plant available water. In 36 establishments of farmers in western region of Santa Catarina State samples were collected from these soil classes in crop-livestock integrated systems managed either under minimum cultivation (12 farms), no-tillage (12 farms) and perennial pastures (12 farms). The changes in physical and hydraulic attributes due to the use and management did not compromise the physical quality of the soils from the Western of Santa Catarina State. The storage of water easily available was not affected by the use and management systems studied, but varied among the soil classes. The mean content of fraction of plant available water storage was 31.4 and 49.6\% higher in Inceptisol, in comparison to Oxisol and Alfisol, respectively, in minimum tillage management.
\end{abstract}

Keywords - Water available, water storage, physical properties, porosity.

Resumo - Os usos e manejos em diferentes classes de solo podem alterar a sua qualidade física e influenciar o armazenamento de água disponível para as plantas. Os objetivos deste estudo foram determinar as interferências dos sistemas de uso e manejo nas alterações dos atributos físico-hídricos de Cambissolos, Latossolos e Nitossolos, e verificar os efeitos desses sistemas e das classes de solo no armazenamento de água facilmente disponível. Em 36 estabelecimentos de agricultores familiares da região do extremo oeste catarinense coletaram-se amostras destas classes de solos, em sistemas de integração lavoura-pecuária manejados em cultivo mínimo (12 propriedades), semeadura direta (12 propriedades) e pastagens perenes (12 propriedades). As alterações nos atributos físico-hídricos devido aos usos e manejos não comprometeram a qualidade física dos solos da região. $\mathrm{O}$ armazenamento de água facilmente disponível não foi influenciado pelos usos e manejos, mas variou entre as classes de solos. O conteúdo médio de armazenamento de água facilmente disponível foi 31,4 e 49,6\% superior no Cambissolo, respectivamente em relação ao Latossolo e Nitossolo no manejo em cultivo mínimo.

Palavras-chave - Água disponível, armazenamento de água, propriedades físicas, porosidade. 


\section{INTRODUCTION}

The diversified systems of agricultural production in the Western of Santa Catarina State are constituted by the use of perennial pastures associated to farms handled in notillage or minimal cultivation conducted in crop-cattle integration system. These use and management may cause changes in the hydro-physical properties and influence the storage of water in the soil and its availability to the plants (DALMAGO et al., 2009). The relation of the use and management of soil with the complex dynamic interactions between soil density, total porosity, macro, meso and micropores and the fraction of plant available water can express changes in the physical quality of the soil (ROSSETTI; CENTURION, 2013; VEIGA et al., 2012).

The processes involved in the storage of water and in the physical quality of the soils in the agriculture/grazing integration systems have been investigated, particularly on the changes of hydro-physical properties of soils submitted to different use and management systems (JEMAI et al., 2013; LANZANOVA et al., 2007; MOREIRA et al., 2012). The capacity of storage of water in the soil can be a sensitive indicator to assess the effects of the intensive use of the soil in crop-cattle integration system in the management under no-tillage (FIDALSKI et al., 2008), in which the grazing does not always compromise the physical quality of the soil (BALBINOT JÚNIOR et al., 2009). However, the pressure of animal trampling may increase the compaction in the superficial soil layer (DEBIASI; FRANCHINI, 2012; LANZANOVA et al., 2007), in which the penetration resistance, the macroporosity and the saturated hydraulic conductivity of the soil are the most sensitive indicators of the effects of soil use and management (SILVA et al., 2008).

The no-tillage system usually increases the storage of water in the soil, which may not necessarily result in a bigger availability of water to the plants due to the soil physical restrictions under severe water deficiency (PETRY et al., 2007). The improvement of the soil physical quality in crop-cattle integration system (CIS) has been attributed to the highest production of straw and soil covering (CHIODEROLI et al., 2012); to the lowest temperature variation and lowest water evaporation (VEIGA et al., 2010); the increase of organic matter (BRAIDA et al., 2010); higher mesofauna activity (NICOLOSO et al., 2008) and; an increase in the storage of dynamic of water in the soil (JEMAI et al., 2013).

Considering the lack of information on the topic, the purposes of this work were to determine the effects of the use and management systems on the hydro-physical properties of soils predominantly used in the Western of Santa Catarina State (Inceptisol, Oxisol and Alfisol) and analyze the effect of such systems and soil classes in the fraction of plant available water.

\section{MATERIAL AND METHODS}

The study was conducted using soil samples collected at 36 settlings of family farming in 21 towns in the Far West of Santa Catarina State, located between $27^{\circ} 16^{\prime} \mathrm{S}$, $53^{\circ} 48^{\prime} \mathrm{WO}$ and $243 \mathrm{~m}$ of altitude and $26^{\circ} 27^{\prime} \mathrm{S}, 53^{\circ} 57^{\prime} \mathrm{WO}$ and $848 \mathrm{~m}$ of altitude. The region is at the interface of two climate types, the Cfa, humid subtropical with hot summer and the $\mathrm{Cfb}$, humid temperate climate and warm summer, according to Köppen classification (PANDOLFO et al., 2002). The annual average temperature is $19.3{ }^{\circ} \mathrm{C}$, and the average temperature in the coldest month is $14.2^{\circ} \mathrm{C}$ while in the hottest month it is $25.3^{\circ} \mathrm{C}$, and average monthly insolation of $177 \mathrm{~h}$. The average annual rain ranges from 1430 to $2280 \mathrm{~mm}$, with the total days of rain between 118 to 146 days (PANDOLFO et al., 2002). The topography is rolling ( 8 to $20 \%$ slope) to hilly (20 to $45 \%$ ), with a variable altitude between 200 to $900 \mathrm{~m}$.

The soil samples were collected from orders of soils predominantly found in the region, constituted by Inceptisol, Alfisol and Oxisol (EMBRAPA, 2013) and the use of the soil with perennial pastures and farms, with these being handled without no-tillage system or minimal cultivation, resulting in a crop-cattle integration system (CIS) (VEIGA et al., 2012). The criteria to select the location for the sample collection considered the use and management of soils which have been used for over five years in the same area, according to personal information from the technicians from the Agribusiness Research and Rural Extension Company from Santa Catarina.

The system of no-tillage used in this region is characterized by the sowing with no previous preparation and the maintenance of residues of winter crops or pastures. The minimal cultivation usually consists of one operation with the mechanic scarified or of animal traction followed by one or two operations with leveling grating or ploughing grating. The perennial pastures are usually constituted by summer grass, often over sowed with winter species (oat and/or rye grass). The CIS has the milk cattle grazing as the main activity in over $70 \%$ of the family rural farms, characterized by the use of plantations with annual winter pastures handled by direct grazing, in rotation with annual summer crops, specially maize (VEIGA et al., 2012).

For each soil class and soil use and management system samples were collected at four farms, in the depths $0-0.10,0.10-0.20,0.20-0.40$ and $0.40-0.60 \mathrm{~m}$, in a total of 144 samples ( 3 soils $\times 3$ use and management $\times 4$ layers $\times 4$ farms). In order to collect the samples with preserved structure, stainless steel cylinders of dimensions of about 5.0 $\mathrm{cm}$ diameter and $4.0 \mathrm{~cm}$ height for the two upper layers and $2.5 \mathrm{~cm}$ height for the two lower layer shave been used. The physical-hydrous attributes soil bulk density (Ds), total porosity (Tp), macro (Ma), meso (Me) and micropores (Mi), and penetration resistance (RP), soil water retention curves and granulometry were determined at the Soil Physics Laboratory in Campos Novos/SC, according to methodologies described by Veiga (2011). The organic matter $(\mathrm{OM})$ was predicted using Walkley-Black Method 
Modified enshrined as Embrapa Method, where the organic matter content of the soil (OM) was obtained multiplying $\mathrm{C}$ content by 1,724 factor (EMBRAPA, 1997; ALHO et al., 2014).

The size fraction analysis was carried out by using the pipette method. The soil density (Ds) was calculated by the ratio of dry soil and the sample volume (EMBRAPA, 1997). The clay average content of Inceptisol soil, Oxisol and Alfisol was, consecutively, 207, 571 and $556 \mathrm{~g} \mathrm{~kg}^{-1}$. The penetration resistance (RP) was determined in samples with balanced moisture in a tension of $600 \mathrm{kPa}$ in Richards Extractor, using a bench penetrometer equipped with conical shaft $\left(30^{\circ}\right.$ inclination), $150 \mathrm{~mm}$ length, penetration speed of $1 \mathrm{~mm} \mathrm{~s}^{-1}$, and determination scale between 0.4 to $15 \mathrm{MPa}$.

The soil water retention curves have been determined after the saturation of the samples, applying the tensions of $0.2,0.6,2.0$ and $6.0 \mathrm{kPa}$ in a box with sand, the tensions of 20,60, 200 and $600 \mathrm{kPa}$ in the Richards extractor (VEIGA, 2011). Van Genuchten's model was adjusted to the data of volumetric moisture and their respective tensions, using the Soil Water Retention Curve - SWRC program (DOURADO NETO et al., 2000).

The pores classes were determined based on the soil water retention curves, in the following way: the total volume of pores ( $\mathrm{Tp}$ ) corresponds to the volume of water stored in the saturated soil sample; the volume of macropores $(\mathrm{Ma}=$ pores with a diameter $\geq 50 \mu \mathrm{m})$ corresponds to the volume of water extracted between the sample saturation and the tension of $6 \mathrm{kPa}$; the volume of mesopores $(\mathrm{Me}=$ pores with a diameter between 50 and 0.5 $\mu \mathrm{m})$ correspondents to the volume of water extracted between the tensions of 6 and $600 \mathrm{kPa}$; and the volume of micropores $(\mathrm{Mi}=$ pores with a diameter $<0.5 \mu \mathrm{m})$ corresponding to the volume of water retained in the samples in the tension of $600 \mathrm{kPa}$.

The fraction of plant available water (PAW) was estimated by the difference of volumetric moisture between the tensions of $6 \mathrm{kPa}$ and $600 \mathrm{kPa}$, corresponding to the content of water retained in the class of mesopores (VEIGA, 2011). The storage of PAW in the soil was calculated by the product of the volume of PAW and the thickness of each layer and, the total capacity of PAW storage PAW was obtained by adding these.

The hydro-physical properties of soils cultivated under different use and management systems were compared by carrying out analysis of variance, in which the differences between the treatments were checked out through the Scott-Knott test at a 5\% significance level. Factorial Anova was used to test the hypothesis that the types of use and the interaction between them set variations in the fraction of plant available water (PAW). The differences between the PAW averages, for all the factors levels, were then compared through the analysis of nonorthogonal contrasts. Covariance Analysis was used to evaluate the effect of the porosity and sample layers as interfering factors of the effects of use and management and, of the classes of soils on the PAW. The inflation and covariance factors (VIFs) were calculated for the final model in order to check collinearity problems, and Anova was applied to test the adjustment of the final model in relation to null models including only the intercepts.

The comparison tests of averages of the hydrophysical properties, between the use and management systems, were carried out in the Sisvar program (FERREIRA, 2011). The other statistical tests were carried out in the $\mathrm{R}$ software 3.0.1 program using the functions $\mathrm{lm}$ (Anova), aov (contrasts) and GLM (covariance). The normality and homoscedasticity of the data were checked out through the plotting of the residues. All VIF values were lower than 2.0.

\section{RESULTS AND DISCUSSION}

The use and management of the soil provided different changes on the hydro-physical properties (Table 1), while the effect of the use and management systems between the classes was observed only for a group of attributes, in each sample shown, as verified for Ds, Tp, Me and PAW of the Inceptisol. Even in different soils, the effect of different use and management on only some soil physical attributes were noticed by Dalmago et al. (2009), Moreira et al. (2012), Rosseti; Centurion (2013), Spera et al. (2010) and Veiga et al. (2012).

In the evaluation of the effects of use and management system on the soil bulk density (Ds),an increase of Ds is noticed (Table 1), mainly in the 0.10 to 0.20 $\mathrm{m}$ layer of the Inceptisol and Oxisol and in the 0 to $0.20 \mathrm{~m}$ of the Alfisol, which represent evidence of soil compaction. Despite the increase of soil density (Ds) in the surface layers of clay soils (Alfisol), the values of Ds lower than the critical limit $\left(<1.4 \mathrm{Mg} \mathrm{m}^{-3}\right)$ do not indicate damage to the physical quality of the soils, then being similar to the results observed by Lanzanova et al. (2007), Moreira et al. (2012) and Spera et al. (2010).

The total porosity ( $\mathrm{Tp}$ ) presented values which were considered adequate $(>50 \%)$ and, in general, an opposite trend to soil bulk density, in the different use and management systems for all layers of the studied soils (Table 1). The highest values of $\mathrm{Tp}$ in the surface layer were observed in the Oxisol under minimum cultivation and notillage system and in the Inceptisol under perennial pasture, similarly to what has been found in other studies on the changes of soil physical attributes to crop-cattle integration system (CIS) (BALBINOT JÚNIOR et al., 2009; VEIGA et al., 2012), who attributed this higher total porosity and lower soil bulk density to the occurrence of wetting and dry cycles, to the increase of the content of organic matter, higher soil covering, lower grazer pressure and the absence of negative effects of sowing of pastures after the inversion of the soil with disc harrow. 
Table 1. Soil bulk density (Ds), total porosity (Tp), macroporosity (Ma), mesoporosity (Me), microporosity (Mi), fraction of plant available water (PAW), organic matter (OM) and resistance to penetration (RP) of the three soil classes under different use or management, in the Western of Santa Catarina State

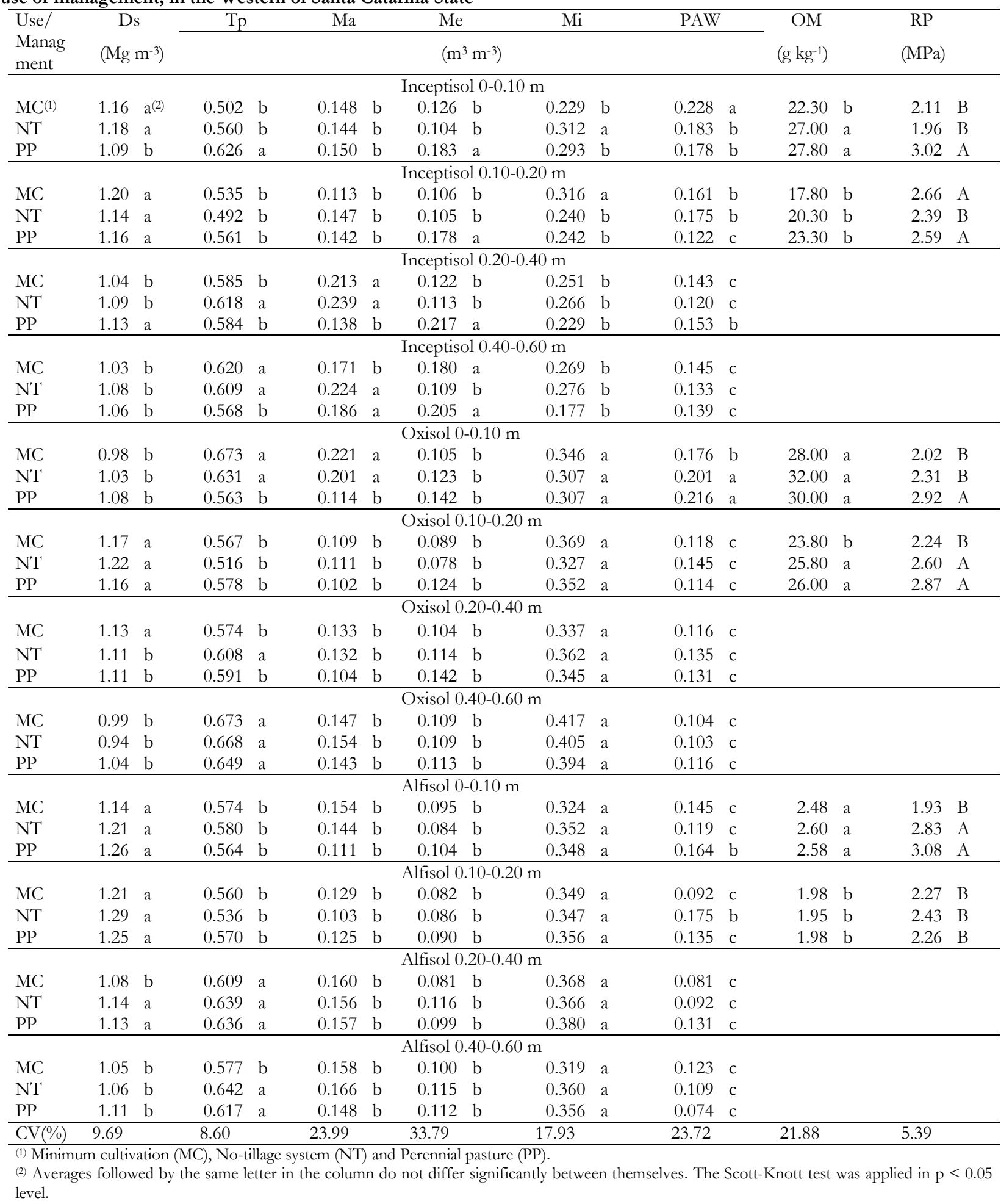

The macroporosity (Ma) presented a behavior similar to the total porosity ( $\mathrm{Tp}$ ), with values considered as adequate $(>10 \%)$ for the diffusion of oxygen in the soil, drainage of the water excess and growth of roots, as described by Tormena et al. (2007). The macroporosity and total porosity values, lower than the critical limits, were attributed to the control of the grazing intensity (3.8 a 4.8 animal unit ha-1) and management of the pasture phytomass $(6.6 \mathrm{~kg}$ of the forage mass to $100 \mathrm{~kg}$ of the animal live weigh), which increase the storage of available 
water and kept the physical quality in a Red Oxisol (FIDALSKI et al., 2008). The same effects were noticed by Silva et al. (2008), in a Red-Yellow Oxisol, in which the resistance to penetration, the macroporosity and hydraulic conductivity of the saturated soil were good indicators of physical changes provoked by the use and management of the soil under a no-tillage system and cultivated pasture.

The absence of variations of mesoporosity (Me) between the Oxisol and Alfisol layers, regardless of use and management (Table 1), may be related to the structural stability and the intrinsic characteristic of the studied soils. Higher values of Me were observed in all layers of the Inceptisol soil with perennial pasture, indicating a favorable condition for the increase of fraction of plant available water (PAW). The distribution of the pore sizes of the Me, responsible for the retention energy of the PAW to the plants, was higher in the surface layers of a Red Oxisol under no-tillage system in relation to the conventional preparation, due to the higher organic matter, higher resistance of the soil aggregates, higher structural stability and the reduction of soil density (DALMAGO et al., 2009).

A behavior opposite to the mesoporosity, the microporosity (Mi) presented higher values in the Oxisol and Alfisol, but there were no significant variations for the use and management systems (Table 1). In these soils, the higher values of Mi may relate to a higher content of clay, differentiating from most of the Mi averages of the Inceptisol soil. Similar results were observed by Spera et al. (2010) in a Red Oxisol, attributing the absence of difference in the Mi between the CIS, due to the structure recuperation after ten years under systems of no-tillage. However, in a Red Oxisol, Torres et al. (2011) found significant variations in the $\mathrm{Mi}$, which presented higher values in native field, indicating that this variable is more resistant to the changes in the use and management systems when compared to the Ma.

The systems of use and management studied in two layers $(0-0.10 \mathrm{~m}$ and $0.10-0.20 \mathrm{~m})$ caused significant differences in the resistance to penetration (RP). In all soil classes the RP of perennial pasture values presented above the critical limit of $2 \mathrm{MPa}$ proposed by Taylor et al. (1966) and, except for the layer $0.10-0.20 \mathrm{~m}$ of the Alfisol, RP values higher than $2.5 \mathrm{MPa}$ considered critical by Petean et al. (2010), which can be attributed to the intensification of animal stamping.

In the surface layer of the handled soils in minimum cultivation, reduced values of resistance to penetration (RP) were observed, between 1.93 to 2.11 $\mathrm{MPa}$ (Table 1), possibly related to scarification and/or harrowing practice in these soils. In all layers and soil classes, in the management under no-tillage system, values lower than the critical limit of $3.5 \mathrm{MPa}$ were observed, considered by Tormena et al. (2007), but very close to that of $2 \mathrm{MPa}$ set by Taylor et al. (1966) and this indicates that a inappropriate use and management of the soils adopted by the farmers in the region of the far west of Santa Catarina.

Similarly to what was found in this study, Balbinot Júnior et al. (2009), Fidalski et al. (2008) and
Spera et al. (2010) noticed changes in attributes such as resistance to penetration (RP), total porosity (Tp) and soil bulk density (Ds) which did not jeopardize the physical quality of the soil. In a Red Oxisol, Rossetti and Centurion (2013) found increases of RP between 1.5 to $3.0 \mathrm{MPa}$, after thirty years of adoption of no-tillage system which do not damage the physical quality of the soil. However, Moreira et al. (2012) observed that the highest RPs reduced the fraction of plant available water in the surface layer of a Red Oxisol under the integrated crop-livestock system (CIS).

The contents of $\mathrm{OM}$ did not present significant variations between the systems of use and management, for each layer of the evaluated soils, except for the layer 0$0.10 \mathrm{~m}$ of the Inceptisol soil and the layer $0.10-0.20 \mathrm{~m}$ of the Oxisol. The highest values of OM (between 24,80 and $32,00 \mathrm{~g} \mathrm{~kg}^{-1}$ ) observed in the surface layer of the three soil classes can indicate the adequate physical quality of the soil, attributed according to Fuentes-Llanillo et al. (2013), to the increase of $\mathrm{OM}$, the keeping of plant residues on the surface layer, the higher biological activity and the lower inversion of the soil. These factors, according to Braida et al. (2010), may reduce the soil susceptibility to compaction and provide positive effects on the water retention, cohesion and soil bulk density.

The different use and management, in the layers and soil classes which were evaluated presented variations in the amount of fraction of plant available water (PAW) between $0.074-0.228 \mathrm{~m}^{3} \mathrm{~m}^{-3}$ (Table 1). However, the content of PAW in the three soil classes was not affected by the systems of use and management (Table 2). This fact may be related with the values of soil density lower than the critical limit $\left(<1.4 \mathrm{Mg} \mathrm{m}^{-3}\right)$ and the distribution of pore volume in the CIS associated with the use and management. It is observed in Table 2 that the soil classes presented significant effect on the PAW $(\mathrm{p}<0.001)$, demonstrating the intrinsic variability (texture, structure, and porosity) to each soil class. In the interaction between the factors use and management with the soils no significant effect in the content of PAW was observed.

Table 2. Effects of the use and management, soils and their interaction on the fraction of plant available water, in the Western of Santa Catarina State

\begin{tabular}{|c|c|}
\hline Fator & $\mathrm{p}^{(1)}$ \\
\hline Use and Man & 0.00120 .9988 \\
\hline Soil $(3)$ & $8.58270 .0003^{*}$ \\
\hline Interaction Use and Management x Soil & 1.84160 .1244 \\
\hline
\end{tabular}

(1) Probability.

(2) Minimum cultivation, No-tillage system and Perennial pasture.

(3) Inceptisol, Oxisol and Alfisol.

* significant at 0.001 probability.

The analysis of contrasts between the management in minimum cultivation and no-tillage system and the use of perennial pasture did not produce statistically significant variations on the values of fraction of plant available water (PAW). Contrary to this effect, the different soil classes provided variations on the PAW, showing significant contrasts (Table 3). 
Table 3. Significance of the contrasts between the systems of use and management and the soil classes on the fraction of plant available water, in the Western of Santa Catarina State

\begin{tabular}{lc}
\hline Contrasts & $\mathrm{p}^{(1)}$ \\
\hline Minimumtillage x No-tillage & $n s^{(2)}$ \\
MinimumtillagexPerennialPasture & $n s$ \\
No-tillage x PerennialPasture & $n s$ \\
Inceptisol x Oxisol & $*$ \\
Inceptisol x Alfisol & $* * *$ \\
Oxisol x Alfisol & $* * *$ \\
\hline
\end{tabular}

(1) Probability.

(2) not significant

* significant at 0.05 probability.

*** significant at 0.001 probability.

The absence of effects from the systems of use and management on the PAW was also noticed by Petry et al. (2007) in a Red Alfisol, where the systems of management under no-tillage system and conventional preparation of the surface layer of the soil did not differ in terms of storage and availability of water for the plants. However, Jemai et al. (2013) identified increase of PAW and improvement in the quality of the soil in the management under no-tillage system, differing from the conventional preparation.

The covariance analysis presented values of factors of inflation and variance (VIF) lower than 2,0 indicating the absence of collinearity for macroporosity $(\mathrm{Ma})$, mesoporosity $(\mathrm{Me})$, total porosity $(\mathrm{Tp})$ and model adequate adjustment (Table 4). The final model does not include the variable $\mathrm{Mi}$ as this presented colinearity. The variation between the systems of use and management did not interfere significantly the PAW, as well as the covariates $\mathrm{Ma}, \mathrm{Me}$ and $\mathrm{Tp}$. The the most pronounced effects on the PAW were due to the variations between the soils and layers. Significance for the Alfisol was checked, and the lowest content of PAW was observed in relation to the other soil classes.

Table 4. Contribution of each soil variable, based on the covariance, on the fraction of plant available water, in the Western of Santa Catarina State

\begin{tabular}{lcccc}
\hline Variable & Coefficient & $\mathrm{EP}^{(1)}$ & $\mathrm{t}^{(2)}$ & $\mathrm{p}^{(3)}$ \\
\hline Intercept & 0.28683 & 0.06792 & 4.223 & -1.248 \\
Macroporosity & -0.00127 & 0.00102 & -2.273 & 0.9720 \\
Mesoporosity & -0.00215 & 0.00095 & -1.794 & 0.0246 \\
Microporosity & -0.00123 & 0.00068 & -0.035 & 0.0752 \\
Soildensity & -0.00127 & 0.03596 & 0.082 & 0.9720 \\
No-tillage & 0.00065 & 0.00785 & 0.448 & 0.9345 \\
PerennialPasture & 0.00375 & 0.00837 & -1.899 & 0.6547 \\
Oxisol & -0.01813 & 0.00955 & -4.273 & 0.0598 \\
Alfisol & -0.04106 & 0.00961 & -5.504 & $<0.001$ \\
Layer $0.10-0.20 \mathrm{~m}$ & -0.05266 & 0.00957 & -6.464 & $<0.001$ \\
Layer $0.20-0.40 \mathrm{~m}$ & -0.05831 & 0.00902 & -6.733 & $<0.001$ \\
Layer $0.40-0.60 \mathrm{~m}$ & -0.06346 & 0.00943 & & $<0.001$ \\
\hline
\end{tabular}

The Inceptisol soil highlights the highest amount of total storage of PAW, in relation to the Oxisol and the Alfisol, respectively, of 31.4 and $49.6 \%$ in the management in minimum cultivation (Figure 1). The highest total storage of PAW of Inceptisol soil may be related to its adequate physical quality. Similarly, Dalmago et al. (2009) found the highest availability of PAW in the surface layers of a Red Alfisol, due to a bigger retention of PAW in the Me class Me, bigger content of OM, aggregates stability, soil structural quality and lower Ds.
The lowest storage of PAW of the Alfisol may be related to the changes of the hydro-physical properties of the CIS. In a Red Oxisol, Petean; Tormena; Alves, (2010), found out that the intensification of animal stamping in CIS caused a reduction of storage of available water and of $\mathrm{Ma}$, increases of Ds, RP and Mi, setting the loss of physical quality of this soil. 


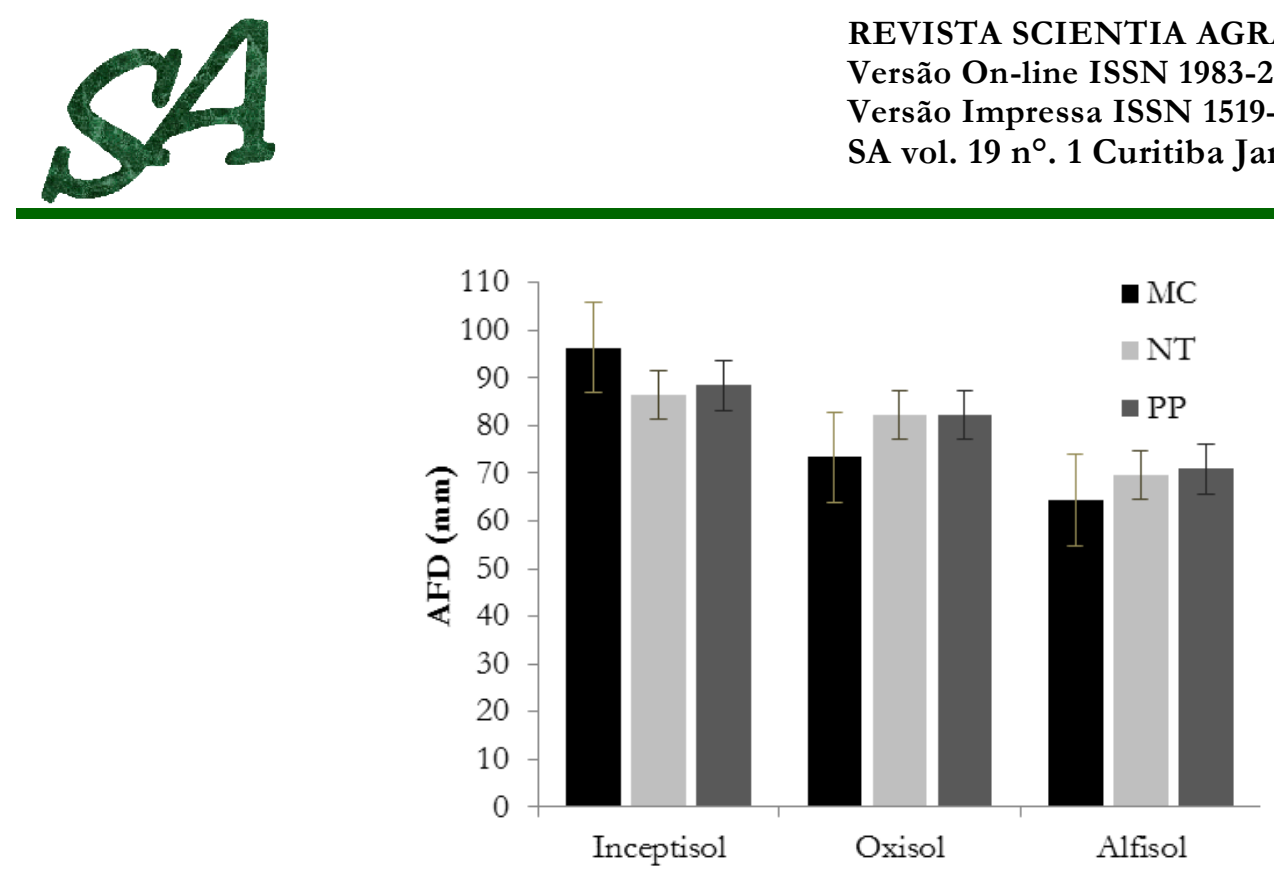

Figure 1. Fraction of plant available water (PAW) in the layer 0-0.60 $\mathrm{m}$ in soils classes under Minimum Cultivation (MC), Notillage system (NT) and Perennial Pasture (PP), in the Western of Santa Catarina State

\section{CONCLUSIONS}

The use and management in no-tillage, minimum cultivation and perennial pasture in different soils of the Western of Santa Catarina State promote changes in the hydro-physical properties which are evaluated, without damaging its physical quality. The amount of fraction of plant available water was not influenced by the systems of use and management, being different between the soil classes in the region. The Inceptisol presents the highest fraction of plant available water, higher than in the Oxisol and Alfisol, respectively, in 31.4 and $49.6 \%$ in the management in minimum cultivation.

\section{REFERENCES}

ALHO, L.C.; CAMPOS, M.C.C.; SILVA, D.M.P.; MANTOVANELLI, B.C.; SOUZA, Z.M. Variabilidade espacial da estabilidade de agregados e estoque de carbono em Cambissolo e Argissolo. Pesquisa Agropecuária Tropical, v. 44, n. 3, p. 246-254, jul./set. 2014.

BALBINOT JÚNIOR, A.A.; MORAES, A. de; PELISSARI, A.; VEIGA, M. da; DIECKOW, J.; NESI, C.N. Propriedades físicas em Cambissolo Háplico manejado sob o sistema de integração lavoura-pecuária. Revista de Ciências Agroveterinárias, v. 8, n. 1, p. 25-34, jan./jun. 2009.

BRAIDA, J.A.; REICHERT, J.M.; REINERT, D.J.; VEIGA, M. da. Teor de carbono orgânico e a susceptibilidade à compactação de um Nitossolo e um Argissolo. Revista Brasileira de Engenharia Agrícola e Ambiental, v. 14, n. 2, p. 131-139, Fev. 2010.
CHIODEROLI, C.A.; MELLO, L.M.M. de; GRIGOLLI, P.J.; FURLANI, C.E.A.; SILVA, J.O.R.; CESARIN, A.L. Atributos físicos do solo e produtividade de soja em sistema de consórcio milho e braquiária. Revista Brasileira de Engenharia Agrícola e Ambiental, v. 16, n. 1, p. 37-43, Jan. 2012.

DALMAGO, G.A.; BERGAMASCHI, H.; BERGONCI, J.L.; KRÜGER, C.A.M.B.; COMIRAN, F.; HECKLER, B.M.M. Retenção e disponibilidade de água às plantas, em solo sob plantio direto e preparo convencional. Revista Brasileira de Engenharia Agrícola e Ambiental, v. 13, (Suplemento), p. 855-864, 2009.

DEBIASI, H.; FRANCHINI, J.C. Atributos físicos do solo e produtividade da soja em sistema de integração lavourapecuária com braquiária e soja. Ciência Rural, v. 42, n. 7, p. 1180-1186, jul. 2012.

DOURADO NETO, D.; NIELSEN, D.R.; HOPMANS, J.W.; REICHARDT, K.; BACCHI, O.O.S. Software to model soil water retention curves (SWRC, version 2.00). Scientia Agricola, v. 57, n. 1, p. 191-192, jan./mar. 2000.

EMBRAPA - Empresa Brasileira de Pesquisa Agropecuária. Serviço Nacional de Levantamento e Conservação de Solos. Manual de métodos de análise de solo. 2 ed. rev. atual. Rio de Janeiro: Embrapa - CNPS, 1997.

EMBRAPA - Empresa Brasileira de Pesquisa Agropecuária. Solos do Estado de Santa Catarina. Rio de Janeiro: Embrapa - CNPS, 2004.

EMBRAPA - Empresa Brasileira de Pesquisa Agropecuária. Sistema Brasileiro de Classificação de Solos. Brasília: Embrapa Informação Tecnológica, 2013. 
FERREIRA, D.F. Sisvar: A computer statistical analysis system. Ciência e Agrotecnologia, v. 35, n. 6, p. 1039-1042, nov./dez. 2011.

FIDALSKI, J.; TORMENA, C.A.; CECATO, U.; BARBERO, L.M.; LUGÃO, S.M.B.; COSTA, M.A.T. Qualidade física do solo em pastagem adubada e sob pastejo contínuo. Pesquisa Agropecuária Brasileira, v. 43, n. 11, p. 583-1590, nov. 2008.

FUENTES-LLANILLO, R.; GUIMARÃES, M. de F.; TAVARES FILHO, J. Morfologia e propriedades físicas de solo segundo sistemas de manejo em culturas anuais. Revista Brasileira de Engenharia Agrícola e Ambiental, v. 17, n. 5, p. 524-530, Mai. 2013.

JEMAI, I.; BENAISSA, N.; BENGUIRAT, S.; BENHAMMOUDA, M.; GALLALI, T. Impact of three and seven years of no-tillage on the soil water storage, in the plant root zone, under a dry subhumid Tunisian climate. Soil \& Tillage Research, Amsterdam, v. 126, n. 1, p. 26-33, 2013.

LANZANOVA, M.E.; NICOLOSO, R. da S.; LOVATO, T.; ELTZ, F.L.F.; AMADO, T.J.C.; REINERT, D.J. Atributos físicos do solo em sistema de integração lavourapecuária sob plantio direto. Revista Brasileira de Ciência do Solo, v. 31, n. 5, p. 1131-1140, set./out. 2007.

MOREIRA, W.H.; BETIOLI JÚNIOR, E.; PETEAN, L.P.; TORMENA, C. A.; ALVES, S.J.A.; COSTA, M.A.T.; FRANCO, H.H.S. Atributos físicos de um Latossolo Vermelho distroférrico em sistema de integração lavourapecuária. Revista Brasileira de Ciência do Solo, v. 36, n. 2, p. 289-400, mar./abr. 2012.

NICOLOSO, R. da S.; LOVATO, T.; AMADO, T.J.C.; BAYER, C.; LANZANOVA, M.E. Balanço do carbono orgânico no solo sob integração lavoura-pecuária no sul do Brasil. Revista Brasileira de Ciência do Solo, v. 32, n. 6, p. 2425-2433, nov./dez. 2008.

PANDOLFO, C.M.; BRAGA, H.J.; SILVA JÚNIOR, V.P. da; MASSIGNAM, A.M.; PEREIRA, E.S.; THOMÉ, V.M.R.; VALCI, F.V.A. Atlas climatológico do estado de Santa Catarina. Florianópolis: EPAGRI, 2002.

PETEAN, L.P.; TORMENA, C.A.; ALVES, S.J. Intervalo hídrico ótimo de um Latossolo vermelho distroférrico sob plantio direto em sistema de integração lavoura-pecuária. Revista Brasileira de Ciência do Solo, v. 34, n. 5, p. 15151526, set./out. 2010.

PETRY, M.T.; ZIMMERMANN, F.L.; CARLESSO, R.; MICHELON, C. J.; KUNZ, J.H. Disponibilidade de água do solo ao milho cultivado sob sistemas de semeadura direta e preparo convencional. Revista Brasileira de Ciência do Solo, v. 31, n. 3, p. 531-539, mai./jun. 2007.
ROSSETTI, K. de V.; CENTURION, J.F. Sistemas de manejo e atributos físico-hídricos de um Latossolo Vermelho cultivado com milho. Revista Brasileira de Engenharia Agrícola e Ambiental, v. 17, n. 5, p. 472-479, mai. 2013.

SILVA, G.J.; VALADÃO JÚNIOR, D.D.; BIANCHINI, A.; AZEVEDO, E.C. de; MAIA, J.C. de S. Variação de atributos físico-hídricos em latossolo vermelho-amarelo do Cerrado mato-grossense sob diferentes formas de uso. Revista Brasileira de Ciência do Solo, v. 32, n. 5, p. 2135 2148, set./out. 2008. 